Boise State University

ScholarWorks

Educational Technology Faculty Publications and

Presentations

Department of Educational Technology

6-1-2017

\title{
Confessional Technologies of the Self: From Seneca to Social Media
}

Norm Friesen

Boise State University 


\title{
Confessional technologies of the self: From Seneca to social media by Norm Friesen
}

\begin{abstract}
Foucault's general notion of "technologies of the self" provides an invaluable starting point for investigating a range of broadly "confessional" practices and technologies over time - from medieval confession to contemporary forms of networked identity construction. Foucault defines technologies of the self as "reflected and voluntary practices by which men not only fix rules of conduct for themselves but seek to transform themselves, to change themselves in their particular being, and to make their life an oeuvre." These are practices or techniques, in other words, that are both undertaken by the self and directed toward it. Specifically confessional technologies involve a deliberate and often structured externalization of the self, often with the help of a confessor or a confessional text or context. Building on existing work (e.g., by Fletcher and Hall), this paper begins by some of the earliest Western confessional practices and "technologies" as described by Foucault, and then proceeding to explain medieval Christian confession and its subsequent "reformation." Next, by appealing to Louis Althusser's notion of interpellation, it develops this conception of confession further, comparing it finally to today's digital media of social self-disclosure, focusing on Facebook in particular. Such contemporary media, the paper concludes, build upon practices and technologies of the self that have been evolving for centuries, if not millennia.
\end{abstract}

\section{Contents}

Introduction: Confessional technologies of the self

The confessional as a technology of the self

Gutenberg: Print as a technology of the self

Hermeneutic technologies of the self

"From Gutenberg to Zuckerberq:" Digital technologies of the self

\section{Introduction: Confessional technologies of the self}

Foucault defines "technologies of the self" as "reflected and voluntary practices by which men not only fix rules of conduct for themselves but seek to transform themselves, to change themselves in their particular being, and to make their life an oeuvre" [1] . These are practices or techniques, in other words, that are directed towards the self, and that may also be initiated by it. Foucault also understands these practices of the self as broadly pedagogical, referring to the Latin root paideia, as a kind of guiding and teaching oneself to become a full member of society. These practices and techniques, Foucault explains, work to "transform the self," to humanize it and make of it a subject, a kind of work or image. Foucault describes the self as being formed to particular directions or goals - for example, as being remade as knowledgeable, pure, immortal, or as having particular access to the truth [2]. Examples considered by Foucault include religious conversion, religious retreat or withdrawal, and of particular interest here, specific ways of reading and writing for and about the self [ $[3]$.

In his account of textual and verbal self-practices, Foucault describes an early example of a set of practices exercised upon the self, for the sake of the self. Significantly, Foucault's description of this practice of the self also provides one of the few extended discussions of "media technologies" to be found in his work [4]. Indeed, Foucault can be said to identify the spread and development specifically of textual media as a precondition for new technologies of the self in Greek and Roman culture. This occurs, Foucault explains, at a time when writing was evolving from being a record of poetry or dialog to something more monological and "prosaic" in nature: 
In Plato's writings, dialog gave way to the literary pseudodialog. But by the Hellenistic age, writing prevailed, and real dialectic passed to correspondence. Taking care of oneself became linked to constant writing activity. The self is something to write about, a theme or object (subject) of writing activity. That is not a modern trait born of the Reformation or of romanticism; it is one of the most ancient Western traditions. It was well established and deeply rooted when Augustine started his Confessions. The new concern with self involved a new experience of self. The new form of the experience of the self is to be seen in the first and second century when introspection becomes more and more detailed. ... Attention was paid to nuances of life, mood, and reading, and the experience of oneself was intensified and widened by virtue of this act of writing. A whole field of experience opened which earlier was absent. [ㅁ]

Writing becomes a technology of the self first in the sense that it is writing about the self, about one's life, moods and deeds. Second, it becomes writing for the self, in that such writing provides a focus for the present self-examination and also an externalized, "objective" artifact for later reflection. Such writing is also confessional, of course, in that it involves a rather explicit externalization of things proper to the self "nuances of life, mood, and reading." To compare this confessional technology to those discussed later, one might imagine a self externalising that which belongs to it in writing. This externalization then being directed back to the self - to take the form of a new, reflective experience of the self (see Fiqure 1 ).

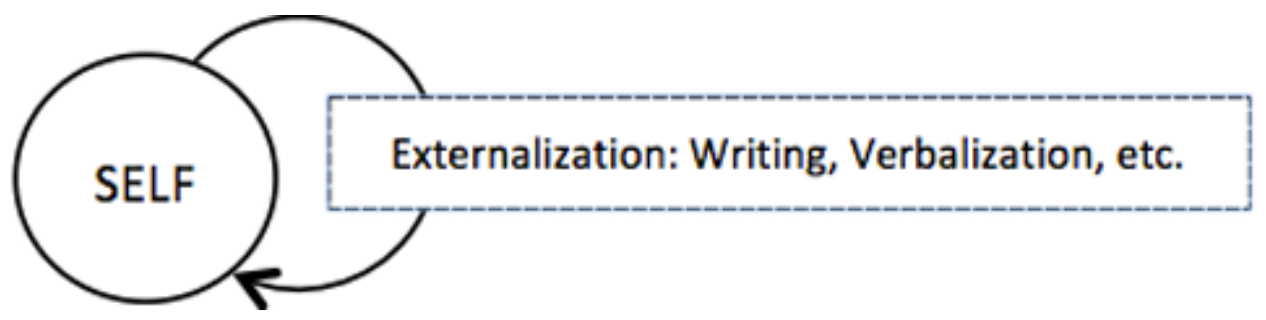

Figure 1: Diagram of a confessional technology of the self, such as reflective writing, in which the self is transformed through operations on itself by means of externalization in one of a number of possible forms.

Taking the example of a letter written by Roman Emperor Marcus Aurelius (121-180 CE) [ㄷ], Foucault notes an important change in this self-practice, one which he identifies with developments occurring over the subsequent millennium, over the course of the Middle Ages (ca. 500-1,500 CE):

[Aurelius'] letter is the transcription of [an] examination of conscience. It stresses what you did, not what you thought. That is the difference between practice in the Hellenistic and imperial periods and later monastic practice. In Seneca too there are only deeds, not thoughts. But it does prefigure Christian confession ... []ㅡ]

The "Christian confession" that Foucault sees as anticipated in the increasing individualization and internalization of self-reflection follows its own trajectory, one which Foucault also addresses. For Foucault, the Christian confessional stands as an expression of specifically Christian forms of renunciation that take place primarily through self-disclosure and verbalization: "from the beginning of Christianity to the seventeenth century," Foucault observes, "there is a correlation between disclosure of the self, dramatic or verbalized, and the renunciation of the self" [8]. Foucault highlights in particular the "inauguration of penance in the thirteenth century [as] ... an important step in its rise" (of dramatic or verbalized self-disclosure). It is this rise, and the pivotal period at the end of the medieval and beginning of the early modern period that this paper now considers.

\section{The confessional as a technology of the self}

Christian confession is relevant as a technology of the self not only in that it offers a link between early and later "versions" of such technologies, but also in that it itself takes the form of a highly standardized technology, one that is systematically expanded and popularized in its use for the masses. This verbalization, significantly, occurs through another (the priest), and this externalization becomes much more structured and internally focused over time. Bossy describes how, over a number of centuries, confessional practice moves broadly from "the field of objective social relations [to one] of interiorized discipline for the individual" [9 $]$. As it occurred in rural communities in the Middle Ages, medieval confession was generally a social and pragmatic affair, a matter of reconciling the penitent or layperson with the parish priest, with his or her neighbors, and 
finally also with the Church (e.g., Figure 2). As Bossey puts it, this type of confession generally took the form of

a face-to-face encounter between two people [the priest and the penitent] who would probably have known each other pretty well in the not-so-remote presence of a large number of neighbors, and more or less at the time ... for the reconciliation to the community of public penitents [, circumstances in which] the average person was much more likely to tell the priest about the sins of his neighbors than about his own. [10]

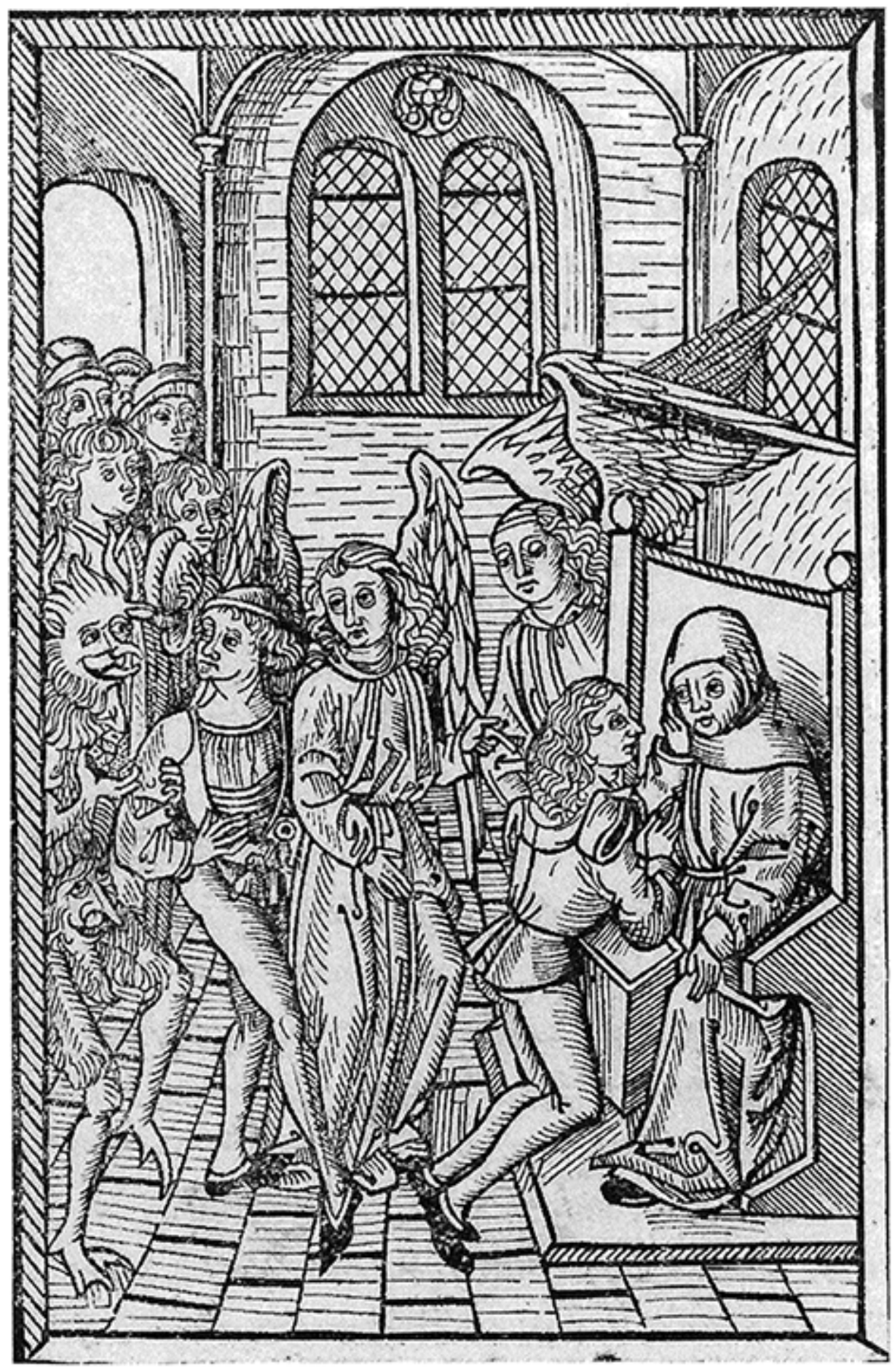

Figure 2: A late medieval confession, 1495. Source: Cornell University Press, used with permission. 


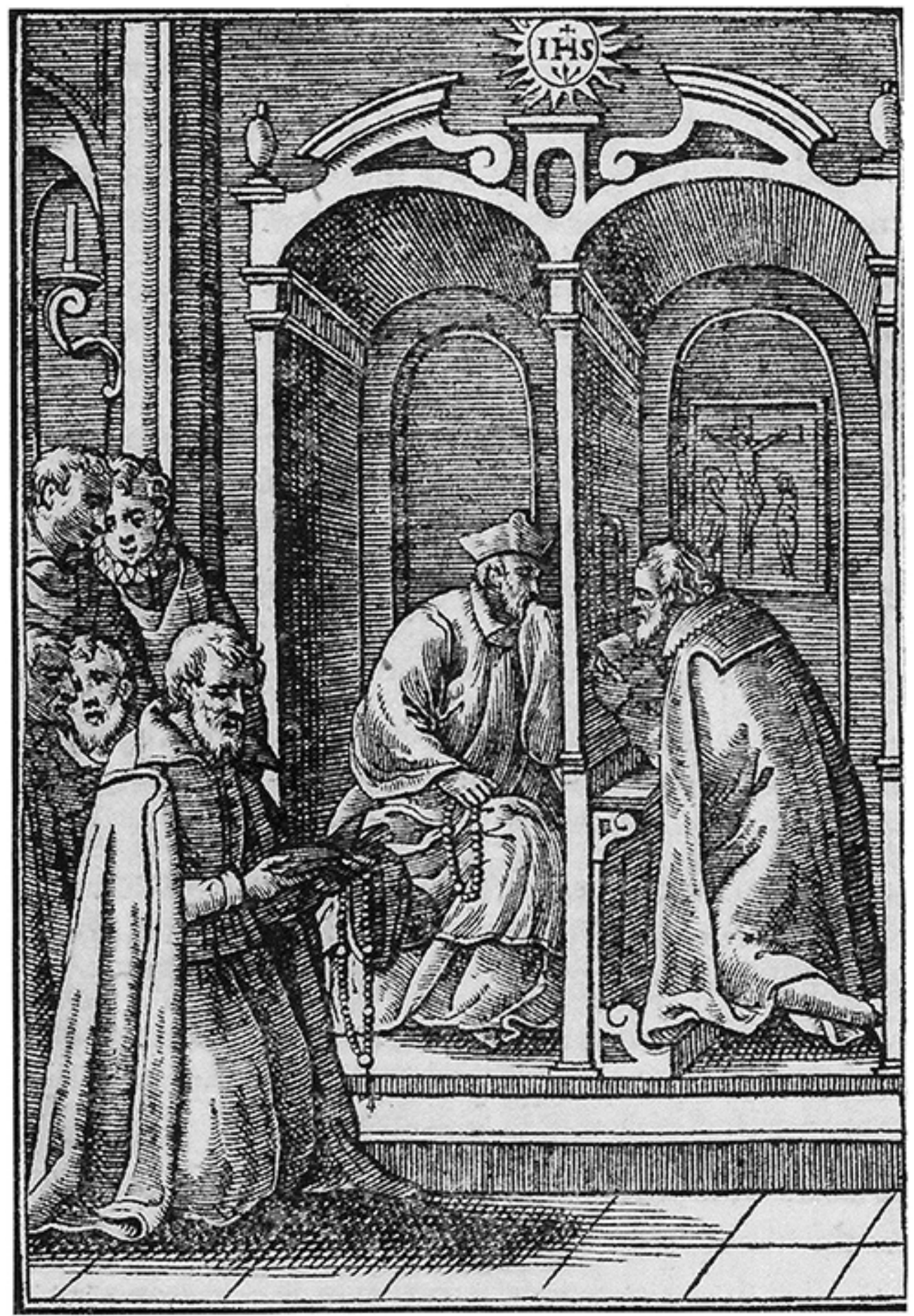

Figure 3: A "model" confessional, built to Borromeo's specifications. Source: Cornell University Press, used with permission.

The emphasis on external deeds noted by Foucault in the ancient, "elite" examination of conscience of Seneca or Aurelius is still very much present in this popular confession for the rural masses. And the medieval confession occurs, notably, without a clear or explicit focus on privacy and reflexivity. This is manifestly evident in Figure 2), which shows not only local parishioners pressing in, but also blocking the way of a devil figure presumably seeking to interrupt the proceedings. For his part, Foucault (1978) highlights the broad cultural significance of the (late) medieval confession as follows: 
confession as one of the main rituals we rely on for the production of truth:

the codification of the sacrament of penance by the Lateran Council in 1215 , with the resulting development of [specific] confessional techniques. [11]

Starting at this early date - when annual confession was first declared as a requirement for all Catholic subjects - the "truthful confession was inscribed at the heart of the procedures of individualization by power" [12] Foucault notes.

However, features of privacy, reflexivity, interiority, and structure are gradually introduced, almost one-byone, into the confession. This corresponds with the spread of what Bossey characterizes as a broad tendency to "psychologize the sacrament" [13]. This took place specifically through the work of Catholic Church leader (St.) Carlo Borromeo (1538-1584), a believer in the importance of confession specifically as "a reconciliation to God and not to the community." [14] "The confession," as Foucault puts it, becomes "a ritual of discourse in which the speaking subject is also the subject of the statement." [15] One of Borromeo's most important innovations was the introduction of "the new technology of the [two- or three-chamber] confessional." (Fiqure 2). [16] Borromeo specified the design of this "furnishing" or "apparatus" (supellectilis) in great detail in his Instructiones fabricae et supellectilis ecclesiasticae (1577). He required, for example, that

A small slightly inclined board [to] ... be set on the upper end. On this the penitent can lean with joined hands while kneeling during confession. This board will be twelve ounces wide and one cubit and a half long [sic]. There will be a step on which the penitent can kneel at the bottom part of this bench. [17]

This precisely specified technology clearly meant to determine the penitent's precise bodily position or attitude, and is also one that gradually spread through early modern Europe. It began in the sixteenth century in the heavily Catholic Latin south, and spread through the Germanic north over the course of some two centuries. As Bossey explains, Borromeo

clearly wanted to seclude both priest and penitent. ... if the confessional was to become an instrument for intimate self-examination, for instruction of the ignorant in the rudiments of Christian doctrine, and for encouraging the denunciation of neighbors to the Inquisition for heresy and similar matters, privacy of a kind was evidently called for. [18]

In this case, we have an environment deliberately designed for "private" and "intimate self-examination;" for the reconciliation of the self to God, and ultimately the renunciation of the self before God. Like the technologies of Facebook and other social media, the Catholic confessional can be said to combine selfdisclosure with functions broadly resembling strategic data collection or surveillance. Such communication is mediated metaphysically through priestly intercession, and physically through through Borromeo's two or three chamber design. The spread of the confessional coincided, as Bossey explains, with "a novel concern for the confession of children, [and] the association of confession with catechism." [19]

\section{Gutenberg: Print as a technology of the self}

The sixteenth century not only marked the introduction of the confessional in the Catholic Church; it also is the time of the rebirth of a slightly different type of "confession" just mentioned by Bossey: the "catechism." The term "catechism" refers to both the published text and the performance that it is intended to script. Its confessional aspect is exemplified in the externalization of what is presumed to be one's innermost faith or belief - an articulation that is itself known as a "confession" of faith. As explained below, ensuring that such an externalization and verbalization was precise and consistent was of the utmost importance. In 1529, Martin Luther published both his "greater" catechism for priests and his "lesser" catechism for lay teachers and lay individuals. Not to be outdone, Borromeo advocated the composition of a Roman Catholic catechism, which was published in 1566, largely as doctrinal instruction for clergy. In the Roman Catechism, the medium of the spoken word as well as the mediating function of the priest are central, as this introductory passage suggests:

But, as "faith cometh by hearing," the necessity of the assiduous labor and faithful ministry of a legitimate teacher, at all times, towards the attainment of eternal salvation is manifest, for it is written, "how shall they hear without a preacher?" And how shall they "preach unless they be sent?" [20]

The people hear the words of the priest - the "ministry of a legitimate teacher" - who has been sent out to them, presumably after having received training at a center of approved learning and instruction. Such a preacher, a verbal communicator of the truth, is clearly the mediator between what is written and the attainment of eternal salvation by those who hear his voice and who are moved by his oratory.

Speech, writing, and meditation are configured rather differently in Luther's lesser catechism, which he introduces as follows:

young and simple people must be taught by uniform, settled texts and forms, otherwise they easily become confused when the teacher to-day 
teaches them thus, and in a year some other way, as if he wished to make improvements, and thus all effort and labor is lost. But with the young people stick to one fixed, permanent form and manner, and teach them, first of all, these parts, namely, the Ten Commandments, the Creed, the Lord's Prayer, etc., according to the text, word for word, so that they, too, can repeat it in the same manner after you and commit it to memory.

(Luther, 1986; emphasis added)

For Luther, the relationship between the text and its readers or audience is to be as direct and immediate as possible. No priestly oratory is to intercede between the authority of God's Word and the confession of His believers. Both the teacher and student are to be taught in "the same manner," and are not separated by acts of priestly mediation. All of the parts of the catechism are to be "repeat[ed] in the same manner after you and [thus] commit[ed] to memory." The language here is more one of textual, pedagogical pragmatics than of clerical ministry and legitimacy based in priestly mediation.

Specifically as Luther describes it, the catechism depends on a mediatic precondition that may be as important as prosaic, "non-dialogical" writing was in Foucault's account of Hellenic technologies of the self. For it is only printed texts that are entirely "uniform" and "settled." Only through mass production enabled by printing can many such identical words be truly and completely memorized "according to the text, word for word" by masses of people. Before the printing press, invented only about 80 years before Luther's injunctions, variation and error in hand-copied manuscripts made any one copy distinct from another. This simple fact rendered any literal, "word-for-word" learning effectively impossible. (It also rendered moot commonplace notions of publication dates, successive editions, or corrections.) While some attributed the flawlessness and precision of print - down to the smallest flaw or typo - to the devil [21], Luther saw in the printing press nothing less than "God's highest act of grace" [22].

Below is an example of the first page of one of the most famous catechisms or confessions in the wake of Luther's lesser catechism (Fiqure 4).

\begin{tabular}{|c|c|}
\hline 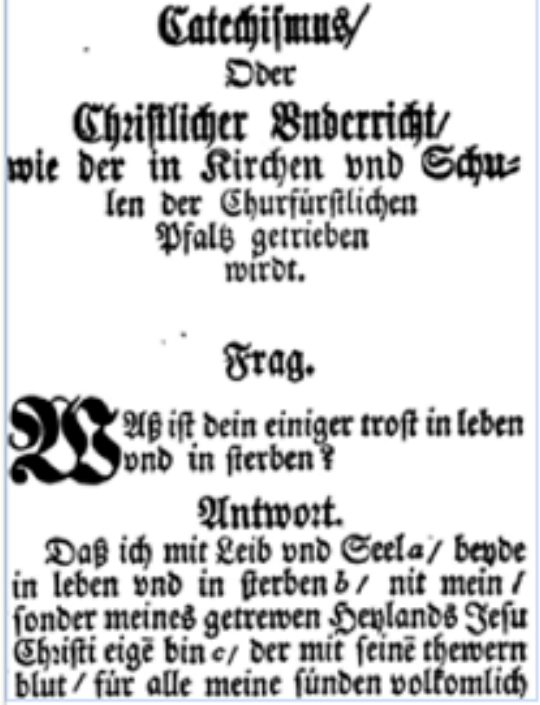 & $\begin{array}{l}\text { Catechism } \\
\text { Christian Instruction } \\
\text { as it is undertaken in churches and schools in the Palatinate. } \\
\text { Question. } \\
\text { What is your only comfort in life and death? } \\
\text { That I, belong with body and soul / both in life and in death / not } \\
\text { to myself, but to my faithful Saviour Jesus Christ / who fully } \\
\text { paid for all my sins with His precious blood, and has set me } \\
\text { free... }\end{array}$ \\
\hline
\end{tabular}

Figure 4: Opening page of the original Heidelberg Catechism from the 1560 s and in translation. Source: Wikimedia Commons; translation from Centre for Reformed Theology and Apologetics, 2012.

In this example, the catechist is significantly addressed as "you." The text asks him or her about "your only comfort in life and death," and scripts the catechist's answers in the first person: "That $I$, belong ... not to myself, but to my faithful Saviour." In thus scripting questions and their answers, this catechism and many others like it deploy a discursive technique indispensable for educational technologies of the self during the Reformation and for centuries after. For it not only directly addresses those reading and reciting, but in so doing, quite literally "transform[s] them into ... Christian religious subjects," at least according to one analysis. This is the reading of Louis Althusser, one of Foucault's teachers in Paris. In reading and reciting words about their life and death, body and soul, Althusser explains, catechists hail or call their readers to play or internalize a certain role, to say certain things about themselves and their lives. Catechists, in other words, place themselves in the position of the "I" and the "you" in the text, and recognize themselves as being thus positioned. Althusser refers to this as "interpellation." As Althusser explains, the subject is asked to respond: "Yes; it really is me!" allowing them to "obtain from" such a text "the recognition that they [as readers] really do occupy the place it designates for them as theirs in the world, a fixed residence" [23]. 
Catechists are asked questions, and their answers are scripted from identical printed texts; in this way, they can be said to be placed directly in the positions articulated in the text, leaving no room for doubt, doctrinal variance, or strife. Through this technique or phenomenon of the self - itself often known as a "confession of faith" - the catechist becomes a "subject," specifically, a confessing, pious, doctrinally-conformant subject. As Althusser explains, such a subject freely takes on an established role and identity, willingly subject-ing him- or herself to God's own position or role:

this 'procedure' to set up Christian religious subjects is dominated by a strange phenomenon: the fact that there can only be such a multitude of possible religious subjects on the absolute condition that there is a Unique, Absolute, Other Subject, i.e., God. God thus defines himself as the Subject par excellence, he who is through himself and for himself ("I am that I $\mathrm{am}^{\prime \prime}$, and he who interpellates his subject, the individual subjected to him by his very interpellation. [24]

Through the technology of the self of the confessional catechism, the catechist is effectively aligned under God, and can be said to become a self and subject through the assistance of a teacher, but also more importantly, through the absolute selfhood of God (see Fiqure 5).

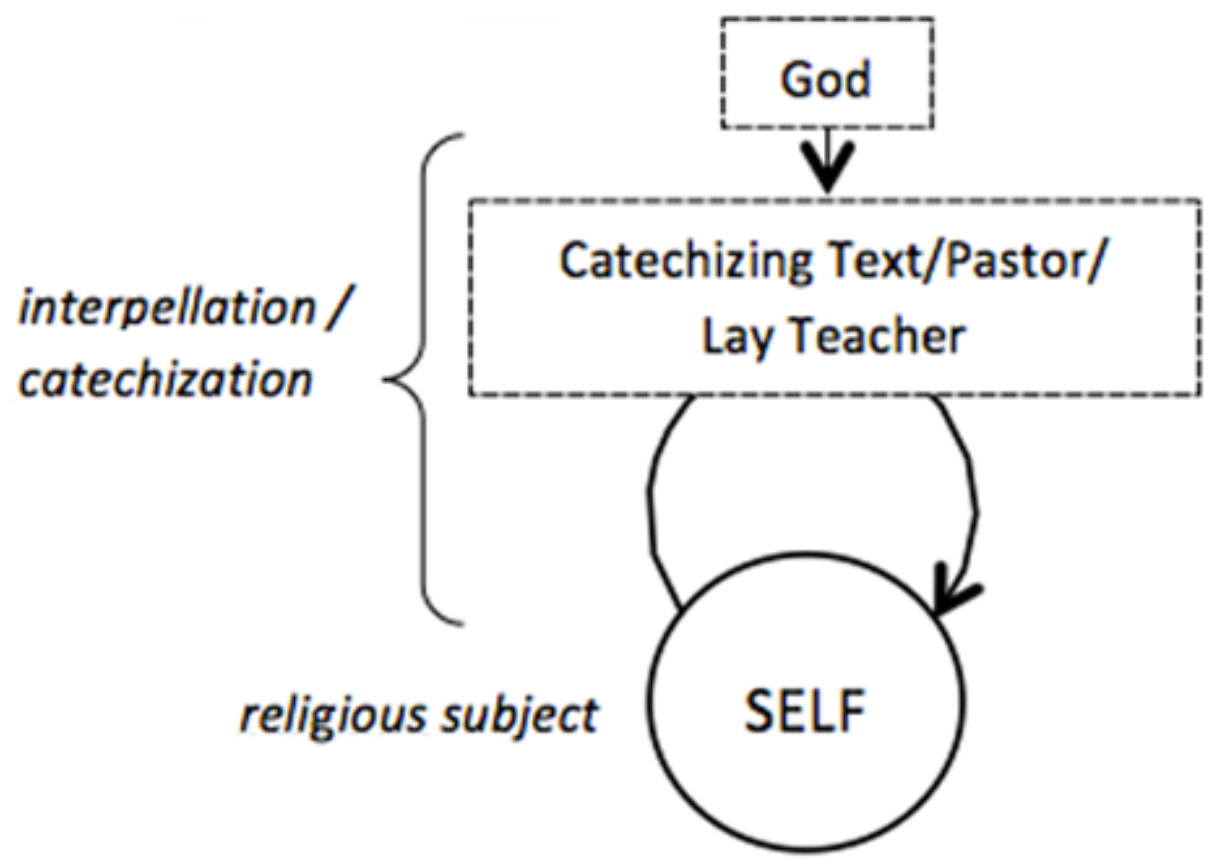

Figure 5: A catechetical technology of the self, in which the self can be seen as positioned or interpellated through catechetical recitation. This recitation occurs through reference to an absolute self (God) and authorized knowledge (text). The catechist is effectively aligned under God, and can be said to become a self and subject typically through the assistance of a minister but also more importantly, through the absolute selfhood of God.

Notably, Foucault - unlike his teacher Althusser - does not hold up the (counter-)reformational catechism as an exemplary instance of the construction of identity and subjectivity. However, Foucault does identify a further characteristic of the early-modern self that is clearly illustrated in this religious form or practice. This is a correlation between the verbalized disclosure of the self on the one hand, and its self-renunciation on the other:

This theme of self-renunciation is very important. Throughout Christianity there is a correlation between disclosure of the self, dramatic or verbalized, and the renunciation of self. My hypothesis from looking at these two techniques is that it's the second one, verbalization, which becomes the more important. [25]

In keeping with Foucault's characterization, the catechism typically took the form of questions asked by a teacher and verbalized answers provided by a group of students. The entering into this process is clearly subsumed or in Foucault's terms, "renounced" in the face of "uniform, settled texts and forms." In the case of 
the Lutheran catechism, these texts include the Ten Commandments and the Lord's Prayer. In these cases the medium of the text reflects neither an earlier experience of the self, nor the result of the self-examination of one's own deeds or thoughts. Instead, it is an exact iteration of previously stated religious truths. Indeed it represents a kind of "subjectivization of [this] truth," to use Foucault's terms [26].

Foucault's observations find still further confirmation in the subsequent history of the catechism, particularly as a pragmatic instructional or pedagogical form. Building on his previous remarks regarding the increasing significance of verbalization and renunciation, Foucault explains:

From the eighteenth century to the present, the techniques of verbalization have been reinserted in a different context by the so-called human sciences in order to use them without renunciation of the self but to constitute, positively, a new self. To use these techniques without renouncing oneself constitutes a decisive break. [27]

Looking at the catechism in in the centuries following the Reformation, this break can be seen in the adaptation of the catechetical form to secular curricula and to the most elementary pragmatics of classroom instruction. Particularly important was the evident efficiency of catechetical techniques, allowing for basic mass education with the barest of means, as J.F. Wakefield observes

If the goal were memorization, the catechetical style eliminated the need for either pedagogical knowledge or subject knowledge on the part of the teacher. The voice of the teacher and the textbook author were not only in agreement, they were the same! [료

These identical, secularized voices of the teacher and textbook author came to take the place of Althusser's Christian God as the subject "par excellence." The subjectivities or selves of the readers are still hailed or interpellated in the secular catechetical text but they are not as explicitly or as fully "renounced" and then reconstituted in their innermost belief through the absolute selfhood of an all-powerful God. Instead, the self, or more specifically, its words or academic knowledge become those of the infallibly reproduced text of the teacher and textbook. Teacher, textbook, and textbook author in short replace "God" as well as "Catechizing Text, Pastor and Lay Teacher" that are shown in Fiqure 5. It is these sources that represent a kind of paradigmatic, but hardly absolute or omniscient, knowing subject, through whom the teacher, and in particular, the student, are positioned as "knowledgeable" or "studious." As it came to be used in education, the catechism - typically in the form of answers provided by memory from students in response to questions recited by the teacher - provided a kind of "script" for oral educational performance, one that is potentially suited to any subject or dogma.

The execution of the pedagogy of the catechism calls for an absolute minimum of equipment. Besides the text to be vocalized (held in the teacher's hand), students could be taught without books, paper or any other equipment.

As indicated, as an instructional method utilizing secular material, the "technology" of the schoolroom catechism configures the media of both text and voice in ways that are quite different from their functional interrelationship among Foucault's ancient elite or in early modern Protestant or Catholic confession. Even though verbatim recitation is still the basis of this catechetical technology, the objective of the "secularized" catechism is no longer explicitly one of renouncing the self in front of the authority of the text. Instead, it involves the reinsertion of techniques of verbalization for more immediate and concrete purposes. These are to equip pupils with skills for use in a secular world, rather than preparing their souls for a religious hereafter. In keeping with the educational ideals starting to develop in the "human sciences" - for Foucault, economics, linguistics, biology, history, and philosophy - at the end of the eighteenth century, the verbalization associated with the secular catechism can be seen as working "to constitute, positively, a new self" specifically an educated, even literate self - to again use Foucault's words. However, as early as the beginning of the nineteenth century, this catechetical pedagogy was subjected to significant critique, even among educators of an explicitly religious orientation.

\section{Hermeneutic technologies of the self}

Johann Gottfried Herder, a German Protestant theologian, linguist, and philosopher, targeted catechists in one of his "School address from 1800":

But remember, you catechists: The eternal turning to and drawing from subject to predicate, from predicate to subject: "Who created you? Who (else) did he create?" Is not really catechizing, but actually a kind of bodily "yawning" of the word, in that one moves the mouth up and down, from side to side, resulting in little more than the "giddyap" of a driver of horses. One must catechize in one's own words; one must draw one's own words out from that which is catechized. One's own words: these and these alone signify one's own thoughts. These (words) must one follow, in order to connect one's thoughts with them. In this way, one learns in a teacherly manner, and one teaches in a way akin to learning. [29] 
The true source of knowledge or belief, for Herder, is no longer to be found in the medium of the catechetic text. For an exercise of question and answer to have any value, Herder insists it has to occur "in one's own words" directly "signify[ing] one's own thoughts." The verbalization of the author, teacher, and the student can no longer be in agreement or indistinguishable. In the final analysis, Herder is pointing to a return of the technology of the self to serve the modern self in a way similar to its function in ancient Rome. Written words, in both cases, offer an occasion for the enunciation of a response, a response which can be external and aloud, or internal and silent. Of course, there remains an important difference: Instead of the self directly recording its experiences and actions sui generis, Herder sees it as responsive to catechetical or other textual media it has before it: "one must draw one's own words out from that which is catechized." In this case, Foucault's "hermeneutics of the self" become, in a sense, a hermeneutics of the text: Knowledge is seen as having its origin in oneself, in one's own "thoughts," perhaps as prompted by the text, but certainly not as predetermined by uniform, settled wording. In this way, a rather different set of possibilities for experiencing the self are opened up. The self, one's own thoughts and mental powers, are confirmed as a source of knowledge in and of themselves, as capable of formulating or constructing knowledge that is in a sense "new."

Another German-speaking romantic, educator Johann Heinrich Pestalozzi, was also critical of the catechism as a teaching tool, directing his critique specifically to the Heidelberg Catechism. Pestalozzi was the first to seize upon a textual method that would assist students to "draw their own words out from that which is [otherwise] catechized" or written down before them. Pestalozzi introduced what he simply called his "method," also known as the "inductive method" or "Pestalozzian method." This is a kind of technology of the self that, like the catechism, also addresses the student or the reader directly, but simultaneously encourages a kind of internalization of this engagement. Through Pestalozzi's method, children are simply asked for answers based either on their existing knowledge or relatively simple inductive reasoning - always in reference to common, everyday experiences. Pestalozzi wanted to address the child on the level of the world that he or she encountered everyday, for example, the roundness of the ball at play, the tallness of the tree, or the number of toes on one's feet and fingers on one's hands.

Like Herder, Pestalozzi believed that "the child is fettered ... [in] all catechizing," and further that "sense impression of Nature [sic] is the only true foundation of instruction." [30] Pestalozzi's method asked that any textbook used for children base all of its lessons on what could be safely assumed to be the common experience or a correct inductive response from what had been learned previously. This "inductive method" quickly spread from Europe to America, arriving in 1821 in the form of a textbook entitled First lessons in arithmetic. This "first Pestalozzian textbook had a tremendous influence on all subsequent arithmetic textbooks. Its main contribution," one historian explains, "was to construe mathematics as a process of observation rather than as a 'ciphering' procedure. (How many thumbs do you have on your right hand? How many on your left? How many on both together?)." [31]

In this way, inductive questions posed in the text can be said to serve as prompts for a kind of engagement of the reading self with itself, an engagement that is neither entirely scripted nor simply mnemonic in character, but rather the result of individual recollection and logical induction. Here the self is invoked in the text not as the subject of religious or even secular dogma. Instead, this self is seen as the source of its own knowledge, articulating an answer in its own words. The selfhood or subjectivity of such a self, at least in this modest sense, can be said to be self-authored.

This understanding of the self, of the mind and its capacity to synthesize and generate knowledge is important if not inescapable today, in social educational, and other contexts. We see ourselves as constructing our own stories and life courses. This is how people are seen to become "authentic" individuals: We have our own timelines that we use to explain our past, present, and future. In education today, we see ourselves as constructing knowledge anew based on our experiences, and also developing our identities as individuals, scholars, and professionals as we progress. Many, primarily textual forms - from Web pages through blogging to Twitter - have been studied explicitly as "new," "digital technologies of the self" which "allow the individual's self/selves to emerge publicly and be worked upon ... ." [32] For example, Fletcher (2010) has perceptively connected Foucault's observations on individual and sexual confession to personalized blogging practices. Similarly, Hall (2016) references Foucault's theory of confessional "selfwriting" in developing an "aesthetic genealogy" of a social media sub-genre known as "cue card confession."

\section{"From Gutenberg to Zuckerberg:" Digital technologies of the self}

Confronted with changing configurations of confessional technologies of the self [ $\underline{33}]$, it is not difficult to regard Facebook - a social media site with over one billion registered users - as a powerful, interpellating, confessional technology of the self. As readers will know to (or beyond) the point of forgetting, whether on a smartphone, tablet, or a computer screen, Facebook insistently greets its users with the question: "what's on your mind?"

In its familiarity and simplicity - as well as its use of the first person - this question, and the responses it elicits, offer many connections with the technologies of the self outlined above. The opening question is not entirely dissimilar to those in textbooks using the Pestalozzian or inductive method, which prompt their users to answer questions on their own, in their own words and through reference to their own experience. Asking a user "what's on your mind?" also certainly resonates with Herder's insistence that it is one's own words that "alone signify one's own thoughts." 


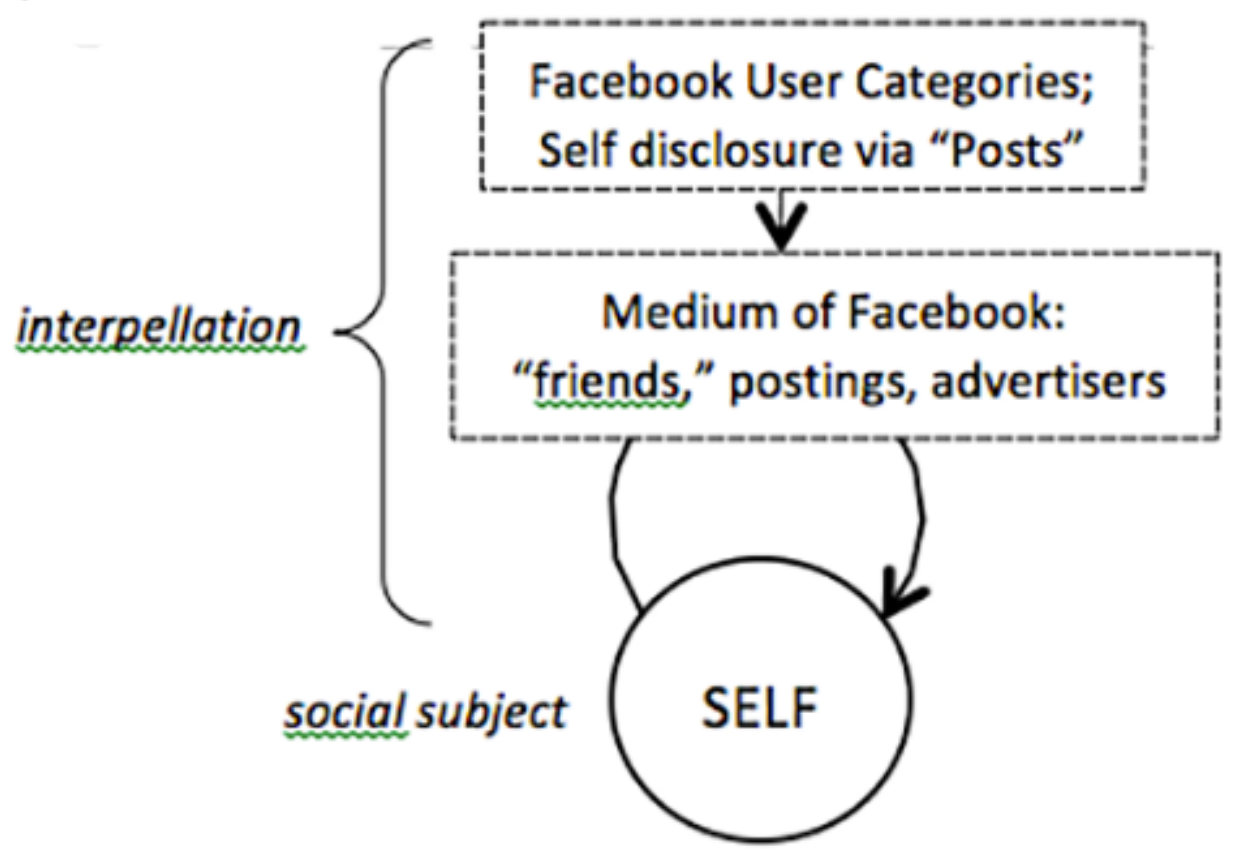

Figure 6: Facebook as an interpellating technology of the self.

However, as Facebook users will also recall, this social media platform does not simply offer opportunities to communicate "what's on your mind," it also requires users to complete a "profile." This amounts to a multipage form to identify one's work and education, as well as "places you've lived" and "worked." And this form even suggests locations and workplaces, and other answers as you type. These forms also asks for contact and other basic information as well as information on family, relationships, life events, and other "details about you." In fact, for some of these categories, Facebook will be rather insistent, asking questions and making suggestions regarding various institutional affiliations, even familial ones, highlighting these at the top of one's Facebook feed.

In other words, Facebook categorizes users according to standardized, predefined classifications - from place names through to relationship types (e.g., wife, sister, mother) - across multiple pages, forms, or templates. In this way, it possible to speak of users being "interpellated" in Facebook in particularly forceful ways. In formulating or selecting responses to questions about "work" and "education," and "places you've lived," users can be said to be constituted as Facebook subjects, ready for further forms of self-expression and self-disclosure. However, this "subjectification" of users occurs not through a pre-scripted catechism that asks after your only comfort in life and death, but through a kind of "template" of categorized questions that ask after matters of rather similar contemporary importance. Facebook reinforces this categorization in particularly social ways: your year or graduation, your birthday, and other markers and changes in one's personal "status" are open to being broadcast by Facebook to your friends or to the public as a whole. For its part, Facebook is then able to sell this private demographic user information to advertisers at a premium price, allowing very precise targeting of their messages. For example, users can be grouped by neighborhood, multiple interests, age, background, marital status, and more (e.g., Friesen and Lowe, 2012). By following Facebook's links for advertisers, one can find out how much it would cost to sell advertising to males between the ages of 30-45, living in a particular neighborhood, with interests in books, cooking, and vegetarianism.

Of course, the individual subject, and the relation of the self to itself is constituted not only through such demographic categorizations, but also through what this same subject does and communicates on Facebook - their "likes," "posts," and "reposts" shared with friends, family, and acquaintances.. Users are provided with myriad ways of positioning themselves as subjects. Through their many possible responses to Facebook's opening question, "what's on your mind," users are effectively able to affirm: "Yes; it really is me!" as Althusser says. They are able to confirm that "this is what's on my mind," that this is something "I can like or on which I can comment." They are thus able to "obtain from" their engagement with Facebook "the recognition that they really do occupy the place it designates for them as theirs in the world, a fixed residence."

Facebook not only mediates the subject's relationship to itself communicatively, but also provides something akin to the "subject par excellence" that the catechism offers through the "Unique, Absolute, Other Subject [position of] God." However, it is clear that this absolute or universal subject is not scripted as a monotheistic deity, but as the wide range of possible but sometimes predetermined profile attributes, comment types, and 
other options that define or interpellate users according to pre-defined questions and predetermined posting types and behaviors.

This last point is illustrated by a recent news story about the social media platform. As I complete this article, Facebook is described as "struggling" to stop a decline in what one article describes as "sharing." In this case, sharing involves reposting or forwarding posts made by friends, and in particular, the publication of "original broadcast posts," which typically report on personal matters. Instead of these user-authored items, the great majority of Facebook posts consists of content forwarded from news sites and other third party sources, which are associated with lower user interest and engagment: "As of mid-2015," one article explains, "total sharing had declined by about $5.5 \%$ year over year while 'original broadcast sharing' was down $21 \%$ year over year" (Efrati, 2016). "Original broadcast posts" not only represent the principle way that users engage confessionally, through broadly "interpellative" self-disclosure, they are also crucial to Facebook's business model and to the precisely targeted advertising that is its principle source of revenue. These "shared" and "original broadcast posts" not only directly express users' own activities, whereabouts and interests, they also confirm their affiliations - through the inclusion of "tags" referencing those directly involved, and through the likes and comments of others whose interest might be attracted. Facebook has responded to the decrease in these original posts by highlighting personal posts from the past, pushing new posts of this kind to the top of all of its users' feeds. It has also made myriad other minor adjustments to effectively increase the selfreferential nature of posts - and also, in effect, their interpellative power.

What is perhaps most striking from the configuration of this technology of the self outlined in Figure 6 is not how radically different or novel its organization of the self and its interpellation appears, but rather how similar it is to earlier configurations - particularly to catechetical and confessional configurations predating Romantic era. These differences and similarities provide a clear example of how confessional technologies of the self, their theorization in research, and their utilization in practice develop neither synchronously nor cumulatively. The Protestant and Catholic catechisms can be seen to prefigure Facebook's structure and question - "what's on your mind" - as much or more than Pestalozzi's inductive questioning or Herder's insistence on "one's own words." Indeed, one might regard it as a kind of postmodern echo of Descates' eminently rationalist cogito ergo sum - as an equally elemental touchstone for the grounding and validation of self in the early modern era. And the confessional emphasis on the intimate self-examination in Bossey's counter-reformational confessional is echoed in Facebook's tweaks to encourage individual "broadcast sharing," the creation and dissemination of new posts about one's own life, activities and relationships.

Recognizing the strinking similarity of technologies of the self over the centuries of heterogeneous cultural, religious, and instructional practice offers new ways of understanding the educational or self-forming significance of present-day media technologies. For example, the analysis above does not suggest that these technologies work as networks and flows of information for personalized learning (e.g., Johnson and Sherlock, 2012) nor that they provide affinity spaces for shared literacy practices (e.g., Gee 2015). Instead, this paper shows that these technologies have long offered those engaged with them "a certain number of operations on their own bodies and souls, thoughts, conduct, and way of being," as Foucault says. It indicates that these technologies are part of a set of possible configurations for forming and mediating a subject and its position - whether as religious, learned, or simply widely "liked." It also suggests that this mediation is varied through innovation in media technologies, but perhaps more importantly, through the multiple ways in which the self is able to be transformed, or to make of itself an oeuvre - whether through the efforts of another or through its own initiative. Indeed, the present use of text and writing to elicit such dialog with others and also with oneself appears little different from the use of inductive and also catechetical texts over the last 450 years, and it has clear resonance with Aurelius' elite writing techniques some 2,000 years earlier. And as Foucault himself observed, over the course these millennia, "the confession" has become "one of the West's most highly valued techniques for producing truth." [34] And taken in a broad sense, it obviously still remains so today. FM

\section{About the author}

Norm Friesen is associate professor in educational technology at Boise State University. E-mail: normfriesen [at] boisestate [dot] edu

\section{Notes}

1. Foucault, 2005, p. 61; see also Foucault, 1985, p. 10.

2. See Foucault, 2005, p. 46; 1988, p. 18.

3. See Foucault, 1988, pp. 27-33.

4. As I observe in Media - Form - Education (forthcoming), "Foucault carefully avoids discussion of contemporary media in his work; he concerns himself more generally with written 'discourse' and the ways that power and knowledge are shaped historically in and through it. Indeed, as Friedrich Kittler observes, 'all [of Foucault's] ... analyses end immediately before that point in time at which other media penetrated the library's stacks' (Kittler, 1999, p. 5). Foucault even insists at one point in his disinterest in all things McLuhan: 'I am not saying that writing would have to be replaced by other communication media not dependent on letters. This is not about McLuhan.'"

5. Foucault, 1988, pp. 27-28. 
6. For example, here is the opening of Aurelius' text, which is quoted at some length by Foucault: "We are well. I slept somewhat late owing to my slight cold, which seems now to have subsided. So from five A.M. till 9, I spent the time partly in reading some of Cato's Agriculture, partly in writing not quite such wretched stuff, by heavens, as yesterday." (Foucault, 1988, p. 27)

7. Foucault, 1988, p. 30.

8. Foucault, 1988, p. 47.

9. Bossey, 1975, p. 21.

10. Bossey, 1975, p. 24.

11. Foucault, 1978, p. 58.

12. Foucault, 1978, pp. 58-59.

13. Bossey, 1975, p. 30.

14. Bossey, 1975, p. 22; emphasis added.

15. Foucault, 1978, p. 61.

16. Bossey, 1975, p. 38.

17. Borromeo, 1981, p. 83.

18. Bossey, 1975, p. 30.

19. Bossey, 1975, p. 38.

20. Pius V, 1829, p. 2.

21. Daniel Defoe writes in the eighteenth century of the "famous doctors at the faculty in Paris" responding as follows to the careful inspection of a set of printed texts:

\begin{abstract}
they observed the exact agreement of every book, one with another, that every line stood in the same place, every page a like number of lines, every line a like number of words ; if a word was mis-spelt in one, it was mis-spelt also in all, nay, that if there was a blot in one, it was alike in all; they began again to muse, how this should be ; in a word, the learned divines not being able to comprehend the thing, (and that was always sufficient, ) concluded it must be the Devil, that it was done by magic and witchcraft ... (1728, p. 325)
\end{abstract}

22. Eisenstein, 1979, p. 374.

23. Althusser, 1984, p. 52.

24. Althusser, 1984, p. 53.

25. Foucault, 1988, p. 47.

26. Foucault, 1988, p. 34.

27. Foucault, 1988, p. 49.

28. Wakefield, 1998, p. 5.

29. Herder, 1953, p. 732. The last line in this quotation reads in the original: "so lernt man lehrend, und so lehrt man lernend" (literally: "thus one learns teaching-ly and teaches learning-ly").

30. Pestalozzi, 1894, pp. 101, 200.

31. Coulburn, 1821, p. xii.

32. Dervin and Abbas, 2009, p. 3.

33. The title of this section is borrowed from a book by John Naughton (2014) which focuses on "Disruptive innovation in the age of the Internet." My emphasis in this paper is precisely the opposite: to highlight continuities in practices of the self that stretch beyond Gutenberg to Zuckerberg - extending, of course, back to the Middle Ages and ancient Rome.

34. Foucault, 1984, p. 59.

\title{
References
}


L. Althusser, 1984. Essays on ideology. London: Verso.

C. Borromeo, 1981. "Instructiones fabricate et supellectilis ecclesiasticae, 1577, Book I, a translation with commentary and analysis," at http://evelynvoelker.com, accessed 15 October 2013.

J. Bossey, 1975. "The social history of confession in the age of the Reformation," Transactions of the Royal Historical Society, volume 25, pp. 21-38.

doi: http://dx.doi.org/10.2307/3679084, accessed 12 May 2017.

F. Dervin and Y. Abbas, 2009. "Introduction," In: Y. Abbas and F. Dervin (editors). Digital technologies of the self. Newcastle upon Tyne: Cambridge Scholars, pp. 1-11, and at http://www.cambridgescholars.com/download/sample/58537, accessed 12 May 2017.

A. Efrati, 2016. "Facebook struggles to stop decline in 'original' sharing," The Information (7 April), at https://www.theinformation.com/facebook-struggles-to-stop-decline-in-original-sharing, accessed 12 May 2017.

P. Fletcher, 2010. "Foucault on confession" (10 August), at http://peterfletcher.com.au/2010/08/10/foucaulton-confession/, accessed 12 May 2017.

M. Foucault, 2005. The hermeneutics of the subject: Lectures at the Collège de France 1981-1982.

Translated by G. Burchell. New York: Palgrave-Macmillan.

M. Foucault, 1988. "Technologies of the self," In: L. Martin, H. Gutman and P. Hutton (editors). Technologies of the self: A seminar with Michel Foucault. Amherst: University of Massachusetts Press, pp. 16-49.

M. Foucault, 1984. "Nietzsche, genealogy, history," In: P. Rabinow (editor). The Foucault reader. New York: Pantheon, pp. 76-100.

M. Foucault, 1978. History of sexuality. Volume 1: An introduction. Translated by R. Hurley. New York: Pantheon.

N. Friesen and S. Lowe, 2012. "The questionable promise of social media," International Journal of Computer Assisted Learning, volume 28, number 3, pp. 183-194.

doi: http://dx.doi.org/10.1111/j.1365-2729.2011.00426.x, accessed 12 May 2017.

K. Hall, 2016. "Selfies and self-writing: Cue card confessions as social media technologies of the self," Television \& New Media, volume 17, number 3, pp. 228-242.

doi: http://dx.doi.org/10.1177/1527476415591221, accessed 12 May 2017.

J. Herder, 1953. "Vitae, non scholae discendum," In: J. Herder. Werke in zwei bänden. München: Hanser.

F. Kittler, 1999. Gramophone, film, typewriter. Translated, with an introduction, by G. Winthrop-Young and M. Wutz. Stanford, Calif.: Stanford University Press.

M. Luther, 1986. "The small catechism," at http://bookofconcord.orq/smallcatechism.php, accessed 12 June 2013.

J. Pestalozzi, 1894. How Gertrude teaches her children: An attempt to help mothers to teach their own children and an account of the method. Translated by L. Holland and F. Turner. Syracuse, N.Y.: C.W. Bardeen.

\section{Editorial history}

Received 22 May 2016; revised 24 September 2016; accepted 12 May 2017.

Copyright (c) 2017, Norm Friesen.

Confessional technologies of the self: From Seneca to social media by Norm Friesen.

First Monday, Volume 22, Number 6 - 5 June 2017

http://journals.uic.edu/ojs/index.php/fm/rt/printerFriendly/6750/6300

doi: http://dx.doi.org/10.5210/fm.v22i6.6750 